\title{
Editorial
}

\section{First referral units (FRU): needs focus in Indian context}

\author{
Harshal T. Pandve ${ }^{1}$, Purushottam A. Giri ${ }^{2 *}$
}

\begin{abstract}
${ }^{1}$ Department of Community Medicine (PSM), Smt. Kashibai Navale Medical College, Narhe, Pune, Maharashtra, India ${ }^{2}$ Department of Community Medicine (PSM), Rural Medical College of Pravara Medical Institute of Medical Sciences (Deemed University), Loni, Maharashtra, India
\end{abstract}

\author{
*Correspondence: \\ Dr. Purushottam A. Giri, \\ E-mail: drpgiri14@gmail.com,dr_harshalpandve@yahoo.co.in
}

Copyright: () the author(s), publisher and licensee Medip Academy. This is an open-access article distributed under the terms of the Creative Commons Attribution Non-Commercial License, which permits unrestricted non-commercial use, distribution, and reproduction in any medium, provided the original work is properly cited.

Health care delivery in India has been envisaged at three levels namely primary, secondary and tertiary. The secondary level of health care essentially includes Community Health Centres (CHCs), constituting the First Referral Units (FRUs) and the Sub-district and District Hospitals. The CHCs were designed to provide referral health care for cases from the Primary Health Centres level and for cases in need of specialist care approaching the centre directly. $\mathrm{CHC}$ is a 30-bedded hospital providing specialist care in Medicine, Obstetrics and Gynaecology, Surgery, Paediatrics, Dental and AYUSH. These centres are however fulfilling the tasks entrusted to them only to a limited extent. The launch of the National Rural Health Mission (NRHM) gives the opportunity to have a fresh look at their functioning. For the first time under National Rural Health Mission, an effort had been made to develop Indian Public Health Standards (IPHS) for a vast network of peripheral public health institutions in the country to provide optimal specialized care to the community and achieve and maintain an acceptable standard of quality of care. ${ }^{1}$

As per Rural Health Statistics of India 2013 Report, as on March 2012, there are 4833 Community Health Centres (CHCs) functioning in the country. ${ }^{2}$ According to the norms average population to be covered by Community Health Centre (CHC) is 120000 in plain areas and 80000 in hilly and tribal areas but in many major states of India such as Bihar, West Bengal, Uttar Pradesh, Haryana and Chandigarh, more than 150000 population is served by a community health centre. ${ }^{3}$ About $97 \%$ of $\mathrm{CHCs}$ are located in the Government buildings. The rest are located either in rented building or rent free Panchayat/Voluntary society buildings. ${ }^{2}$ Nearly $3 \% \mathrm{CHCs}$ are steel not having own building. Rented or rent free buildings are not supposed to have recommended structure as per guidelines for building of CHCs. Due to lack of proper buildings the services provided are definitely affected adversely. According to District Level Household and facility Survey (DLHS-3) Report, $67 \%$ of the CHCs have functional Operation Theatre (OT) and $76 \%$ of the CHCs have new born care services. However, the blood storage facility is available only in $9 \%$ of the CHCs which are designated as First Referral Units (FRUs). ${ }^{3}$ It means that still more than $30 \%$ of the CHCs don't have functional OTs and more than $20 \%$ CHCs lack to provide new born care services which definitely affects maternal and child health services adversely. More than $90 \%$ CHCs do not have blood storage facility services which adversely affects emergency services in areas where these CHCs are located.

The community health centres as a first referral unit provide specialized medical care in the form of facilities of surgeons, obstetricians \& gynaecologists, physicians and paediatricians. The current position of specialists manpower at CHCs reveal that as on March, 2012, out of the sanctioned posts, $51.8 \%$ of Surgeons, $40.7 \%$ of Obstetricians \& Gynaecologists, 53.3\% of Physicians and $43.1 \%$ of Paediatricians were vacant. Overall $43.7 \%$ of the sanctioned posts of specialists at $\mathrm{CHCs}$ were vacant. Moreover, as compared to requirement for existing infrastructure, there was a shortfall of $74.9 \%$ of Surgeons, $65.1 \%$ of obstetricians \& gynaecologists, $79.6 \%$ of physicians and $79.8 \%$ of paediatricians. Overall, there was a shortfall of $69.7 \%$ specialists at the $\mathrm{CHCs}$ as compared to the requirement for existing $\mathrm{CHCs}{ }^{2}$

To conclude, the first referral units in India are deficient in case of infrastructure and manpower in many parts of the country adversely affecting health of rural population. There is an urgent need to focus on first referral units to improve the health services in terms of quantity as well as quality. 


\section{REFERENCES}

1. Indian Public Health Standards (IPHS) for Community Health Centre, 2012. Directorate General of Health Services, Ministry of Health \& Family Welfare, Government of India. Available at: http://health.bih.nic.in/Docs/Guidelines/GuidelinesCommunity-Health-Centres.pdf. Accessed 21 June 2014.

2. Government of India. Rural health statistics in India, 2012. Statistics Division Ministry of Health and Family Welfare Government of India. Available at:
http://mohfw.nic.in/WriteReadData/1892s/49279450 2RHS\%202012.pdf. Accessed 21 June 2014.

3. International Institute for Population Sciences (IIPS). District level household and facility survey (DLHS-3), 2007-08, 2010. Mumbai, India: IIPS. Available at: http://www.rchiips.org/pdf. Accessed 21 June 2014; and /INDIA_REPORT_DLHS-3.pdf. Accessed 21 June 2014.

DOI: $10.5455 / 2394-6040 . i j c m p h 20150501$

Cite this article as: Pandve HT, Giri PA. First referral units (FRU): needs focus in Indian context. Int J Community Med Public Health 2015;2:75-6. 